\title{
Proceeding of Biology Education
}

Journal homepage: http://journal.unj.ac.id/unj/index.php/pbe

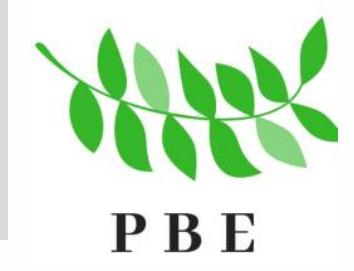

\section{Ketahanan Hidup Benih Ikan Kerapu Bebek (Cromileptes Altivelis) Pada Habitat Air Tawar Sunaryo dan Marmi}

Pendidikan Biologi Fakultas Bahasa dan Sains Universitas Wijaya Kusuma, Surabaya

A R T ICLE INFO

Article history:

Received 22 October 2018

Accepted 31 October 2018

Keywords:

Ketahan hidup, benih ikan kerapu bebek (cromileptes

altivelis), air tawar

\begin{abstract}
AbSTRAK
Diawali penelitian aklimatisasi benih ikan tersebut dari habitat air laut bersalinitas $30 \mathrm{ppt}$ ke air payau bersalinitas 4 ppt dengan kecepatan penurunan salinitas per hari 0,0 ppt (kontrol), 0,5 ppt, $1 \mathrm{ppt}, 1,5 \mathrm{ppt}$, dan 2 ppt. menggunakan sampel benih berukuran panjang berkisar $12 \mathrm{~cm}$ dan berat berkisar $22 \mathrm{gr}$, parameter ujinya adalah survival rate dan respon pertumbuhan. Hasilnya,untuk survival rate setelah dianaliis dengan uji $\mathrm{t}(\mathrm{P} \leq 0,05)$ menunjukkan penurunan salinitas $0,5 \mathrm{ppt} / \mathrm{hari} 35 \%$ berbeda nyata dengan kontrol 92,5\%, namun lebih unggul dibanding perlakuan lainnya yang sudah mati sebelum penelitian berakhir. Sedangkan laju pertumbuhannya diuji dengan anova dilanjutkan uji duncan $(\mathrm{P} \leq 0,05)$ menunjukkan $\mathrm{A}_{0,5} \quad 0,60 \%$ tidak berbeda nyata dengan kontrol $0,61 \%$ tetapi berbeda nyata (paling cepat) dibanding tiga perlakuan lainnya. Penelitian selanjutnya adalah $35 \%$ benih yang hidup dipindahkan ke akuarium yang berisi air bersalinitas $4 \mathrm{ppt}$ selanjutnya salinitas diturunkan $0,5 \mathrm{ppt} / \mathrm{hari}$ sampai dengan $0 \mathrm{ppt}$, parameter yang diamati adalah ketahanan hidupnya. Hasilnya menunjukkan rata-rata ketahanan hidup pada habitat air tawar adalah 21 hari.Kesimpulannya adalah ada kecenderungan ikan kerapu bebek (Cromileptes altivelis) mampu dibudidayakan pada air payau. Untuk sampai ke air tawar perlu dilakukan penelitian lagi dengan waktu yang lebih lama yang ditunjang peralatan pendukung
\end{abstract}

\footnotetext{
*Corresponding e-mail: sunaryohasan@yahoo.co.id
} 


\section{PENDAHULUAN}

Biota laut yang sukses dibudidaya pada tambak air tawar oleh Masyarakat Lamongan dan Gresik Jawa Timur adalah ikan bandeng, udang windu, dan udang vannamei. Budidaya tersebut tergolong unik karena menggunakan air tawar yang berasal dari air hujan. Mereka menurunkan salinitas pada benih udang windu 3 - 4 ppt/hari (Maryadi 2008). Sukses tersebut menimbulkan keinginan budidaya ikan laut yang pangsa pasar eksportnya menggiurkan yaitu ikan kerapu bebek (Cromileptes altivelis) dengan harga berkisar $\mathrm{Rp} 600.000,-/ \mathrm{Kg}$, namun mereka masih enggan mencobanya.

Habitat ikan kerapu bebek pada perairan karang (Cahyaningsih dan Subiyakto, 2003), dengan kisaran salinitas 30-33 ppt, tergolong stenohalin yaitu ikan yang menetap pada perairan tertentu, bertoleransi rendah terhadap perubahan salinitas. Berbeda dengan ikan euryhaline yaitu ikan migrasi yang memiliki toleransi tinggi terhadap perubahan salinitas (Willmer, et al, 2004). Ikan bandeng dan udang tergolong migrasi, bahkan bandeng tergolong euryhaline. Perpindahan biaota laut ke air tawar secara mendadaks dapat menyebabkan stres yang berefek mengganggu proses osmoregulas (Irianto, 2005).

Saat ini belum ditemukan laporan Budidaya ikan kerapu bebek pada air payau. Oktarina, (2009), melaporkan bahwa perendaman ikan kerapu bebek dalam air tawar $2 \mathrm{x}$ 20 menit selama 30 hari pemeliharaan dapat meningkatkan survival ratenya, sedangkan perendaman 1 x paling cepat pertumbuhannya. Kusrahayu dan Sunaryo, (2007), melaporkan bahwa semakin rendah kecepatan penurunan salinitas semakin lama ketahanan hidup benih ikan kerapu bebek. Penelitian ini ingin mengetahui ketahanan hidup benih ikan kerapu bebek pada habitat air tawar.

\section{METODE PENELITIAN}

\section{Rancangan Penelitian}

Penelitian ini merupakan penelitian eksperimental, melanjutkan penelitian tahun pertama. Tahun pertama dengan rancangan acak lengkap 5 perlakuan 4 kali ulangan, tiap ulangan terdiri dari 10 ekor benih ikan kerapu bebek yang berukuran panjang berkisar $12 \mathrm{~cm}$ berat berkisar $22 \mathrm{~g}$. Adapun 5 perlakuan itu adalah $\mathrm{A}_{0}$ sebagai kontrol (penurunan salinitas $0 \mathrm{ppt} / \mathrm{hari}$ ), $\mathrm{A}_{0,5}$ (penurunan salinitas $0,5 \mathrm{ppt} / \mathrm{hari}$ ), $\mathrm{A}_{1}$ (penurunan salinitas $1 \mathrm{ppt} / \mathrm{hari}$ ), $\mathrm{A}_{1,5}$ (penurunan salinitas 1,5 ppt/hari), dan $\mathrm{A}_{2}$ (penurunan salinitas 2 $\mathrm{ppt} / \mathrm{hari}$ ). Penurunan salinitas dari $30 \mathrm{ppt}$ ke 4 ppt dilakukan dengan meneteskan air tawar melalui infuse set (infus untuk pasien di rumah sakit) yang diatur kecepatannya. Hasil penelitian tahun pertama menunjukkan bahwa survival rate kontrol 92,5\% dan $0,5 \mathrm{ppt} / \mathrm{hari} 35 \%$ perlakuan lain mati semua sebelum mencapai 4 ppt. Pada tahun kedua ini $35 \%$ (sebanyak 35 ekor) benih yang hidup tersebut dipindahkan ke akuarium dengan air bersalinitas $4 \mathrm{ppt}$ selanjutnya durunkan salinitasnya $0,5 \mathrm{ppt} / \mathrm{hari}$ sampai dengan 0 ppt kemudian diamati ketahanan hidupnya . 


\section{Waktu dan Tempat Penelitian}

Penelitian dilaksanakan pada tanggal 23 April sampai dengan 10 Agustus 2018 di laboratorium Biologi Fakultas Bahasa dan Sains Universitas Wijaya Kusuma Surabaya.

\section{Alat dan Bahan}

Peralatan yang digunakan adalah akuarium, aerator, filter, infuse set, refraktometer, $\mathrm{pH}$ meter, DO meter, sedangkan bahannya adalah benih ikan kerapu bebek berukuran panjang berkisar $12 \mathrm{~cm}$ dan berat berkisar $22 \mathrm{~g}$, air laut, akuades, dan pakan.

\section{Prosedur Kerja}

1. Akuarium diisi air laut bersalinitas 30 ppt sebayak 100 liter, kemudian diaerasi dengan aerator selama 24 jam. Infus set di pasang pada tandon air tawar untuk meneteskan air tawar, selanjutnya benih dimasukkan. Aerator terus dihidupkan selama penelitian

2. Benih yang lulus hidup pada salinitas 4 ppt dan sudah melewati masa pemulihan dimasukkan dalam akuarium dibiarkan selama 2 hari untuk adaptasi pada akuarium baru, penyiponan tetap dilakukan setiap hari. Pemberian pakan 3 x sehari pukul 06.00, 12.00, dan 18.00

3. Penurunan salinitas dari 4 ppt ke 0 ppt dilakukan dengan kecepatan $0,5 \mathrm{ppt} / \mathrm{hari}$ dengan rumus $\mathbf{V 1} . \mathbf{N 1}=\mathbf{V} \mathbf{2} . \mathbf{N} 2$

4. Selama aklimatisasi dan ketika telah mencapai salinitas 0 ppt diamati ketahanan hidupnya dengan satuan hari.

\section{Parameter Uji}

Parameter uiji pada pelelitian lanjutan ini adalah ketahan hidup benih ikan kerapu bebek pada habitat air tawar (salinitas 0 ppt)

\section{Analisa Data}

Data yang diperoleh adalah rata-rata ketahanan hidup benih ikan kerapu bebek pada habitat air tawar (0 ppt), data tersebut dianalisis secara deskriptif kualitatif 


\section{HASIL DAN PEMBAHASAN}

\section{Ketahanan Hidup}

Tabel Ketahanan hidup Benih Ikan Kerapu Bebek (Cromileptes altivelis) pada Habitat Air Tawar (0 ppt)

\begin{tabular}{|c|c|c|c|c|c|c|c|c|c|}
\hline No. & $\begin{array}{l}\text { Ketahanan } \\
\text { Hidup \{hari) }\end{array}$ & No. & $\begin{array}{l}\text { Ketahanan } \\
\text { Hidup (hari) }\end{array}$ & No. & $\begin{array}{l}\text { Ketahanan } \\
\text { Hidup (hari) }\end{array}$ & No. & $\begin{array}{l}\text { Ketahanan } \\
\text { Hidup }\end{array}$ & No. & $\begin{array}{l}\text { Ketahanan } \\
\text { Hidup }\end{array}$ \\
\hline 1. & 20 & 8. & 21 & 15. & 21 & 22. & 23 & 29. & 20 \\
\hline 2. & 23 & 9. & 21 & 16. & 21 & 23. & 22 & 30. & 21 \\
\hline 3. & 21 & 10. & 20 & 17. & 22 & 24. & 21 & 31. & 20 \\
\hline 4. & 22 & 11. & 22 & 18. & 20 & 25. & 20 & 32. & 20 \\
\hline 5 & 20 & 12. & 23 & 19. & 20 & 26. & 19 & 33. & 21 \\
\hline 6. & 21 & 13. & 21 & 20. & 20 & 27. & 20 & 34. & 22 \\
\hline 7. & 21 & 14. & 22 & 21. & 22 & 28. & 22 & 35. & 20 \\
\hline
\end{tabular}

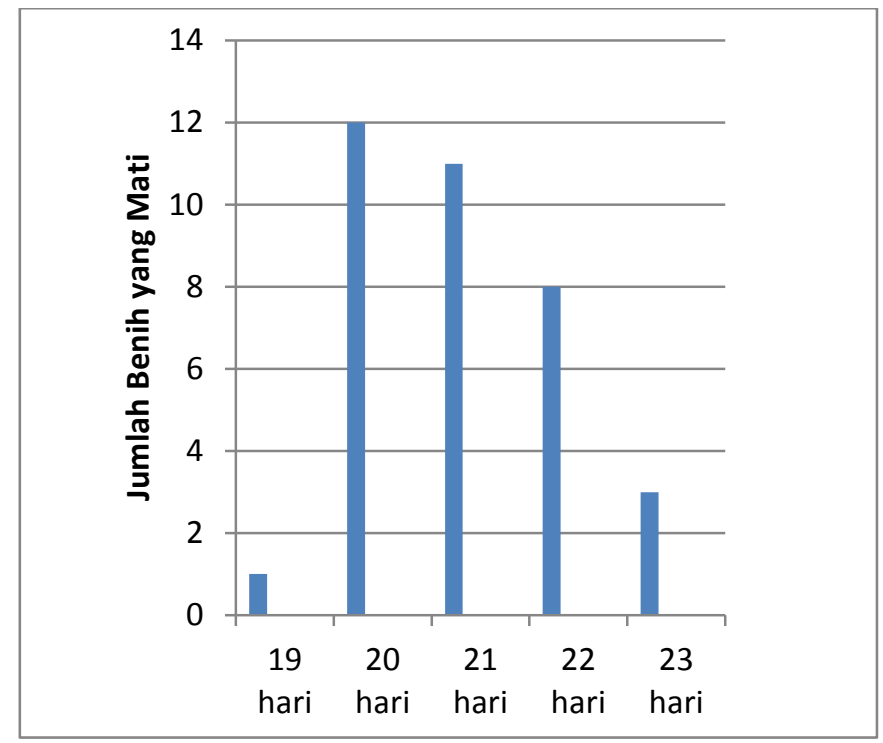

Gambar: Diagram Batang Ketahanan hidup Benih Ikan Kerapu Bebek (Cromileptes altivelis) pada Habitat Air Tawar (0 ppt)

Dari 35 ekor benih ikan kerapu bebek yang dipelihara pada habitat air tawar $(0$ ppt), ketahanan hidupnya tampak pada tabel dan diagram di atas, yaitu paling cepat adalah 19 hari, paling lama 23 hari, dengan rata-rata 21 hari. Hal ini dimungkinkan karena tidak mampu beradaptasi dengan salinitas 0 ppt karena pembenihan buatan ikan tersebut diperlukan salinitas 28-35 ppt (Subyakto, dan Cahyaningsih, 2003). Salinitas adalah sifat fisika kimia air, merupakan ukuran kadar garam terlarut, menentukan karakteristik habitat organisme air. Proses biokimia di dalam dan di luar sel sangat dipengaruhi oleh salinitas (Kultz, 2015). 
Singkatnya waktu (21 hari) ketahanan hidup pada air tawar karena ikan kerapu bebek ini berbeda dengan jenis kerapu lain misalnya kerapu macan (Epinephelus fuscoguttatus) yang adaptasi tingkat atas sampai $35 \mathrm{ppt}$ dan tingkat bawah sampai $0 \mathrm{ppt}$ (Anggoro, 2013). Perubahan salinitas akan menyebabkan stres yang mengganggu homeostasis fisiologis dan proses biologis lainnya. Kemampuan Ikan stenohaline dalam mentoleransi salinitas rendah lebih kecil dibanding ikan euryhaline (Sakuragui, 2007 dalam Kultz, 2015).

Ikan kerapu bebek tergolong stenohalin yang menetap pada perairan tertentu, bertoleransi rendah terhadap perubahan salinitas. Berbeda dengan ikan euryhaline yaitu ikan migrasi yang memiliki toleransi tinggi terhadap perubahan salinitas (Willmer, et al, 2004). Rentang tingkat salinitas habitat awal dengan habitat baru menentukan keberhasilan adaptasi ikan. Sesuai laporan Purcell,( 2008), bahwa ikan rawa air tawar tingkat toleransinya lebih rendah dibanding ikan rawa air payau terhadap peningkatan salinitas. Pada ikan kerapu bebek ini dari habitat bersalinitas 30 ppt diaklimatisasi ke habitat 4 ppt lalu setelah melewati masa stres diaklimatisasi lagi ke habitat 0 ppt.

Waktu yang dibutuhkan untuk pemulihan stres pada ikan ditentukan oleh Stressor (pemicu stresnya). Ikan salmon yang ditempatkan pada air es selama 10 menit membutuhkan waktu pemulihan selama 24 jam, ini lebih rendah dibanding ikan salmon dengan perlakuan Stressor gabungan yaitu habitat dingin dan berenang melawan arus (Rinen, 2004). Pada penelitian ini semakin jauh rentang salinitas antara habitat awal dengan habitat baru semakin tinggi tingkat stressornya.

Pada salinitas media optimal aktivitas osmoregulasi ikan rendah, sedangkan pada salinitas di luar kisaran optimalnya aktivitas osmoregulasi meningkat sehingga jumlah energi yang dibutuhkan juga meningkat (Rachmawati, 2012). Perlakuan dengan penurunan salinitas cepat dengan rentang salinitas dari habitat awal yang jauh memerlukan lebih banyak energi untuk beradaptasi yang menyebabkan energi cadangan menipis yang membuat ikan menjadi lemah dan mudah terserang penyakit, yang pada akhirnya akan mati (Oktarina, 2009).

Rata-rata ketahanan hidup ikan kerapu bebek sebagai ikan stenohalin pada habitat air tawar 21 hari dan tertinggi 23 hari karena aklimatisasinya dilakukan dengan menurunkan salinitas secara perlahan-lahan, seperti yang dilakukan oleh masyarakat Lamongan dalam mengaklimatiasi benih uadang windu dan udang vannamei (Maryadi, 2008).

\section{Kesimpulan}

Kesimpulannya adalah ada kecenderungan ikan kerapu bebek (Cromileptes altivelis) mampu dibudidayakan pada air payau. Untuk sampai ke air tawar (0 ppt) perlu dilakukan penelitian lagi dengan waktu yang lebih lama yang ditunjang peralatan pendukung.

\section{Ucapan Terima kasih}

Terima kasih disampaikan kepada Direktorat Riset dan Pengabdian Masyarakat Direktorat Jenderal Penguatan Riset dan Pengembangan Kementerian Riset, Teknologi, dan Pendidikan Tinggi yang telah membiayai penelitian ini. 


\section{Daftar Pustaka}

Anggoro, S. dkk, 2013, Domestikasi Kerapu Macan (Epinephelus fuscoguttatus), Journal Of Management Of Aquatic Resorces, Volume 2, Nomor 3, Tahun 2013, Halaman 119-127

Irianto, A. 2005. Patologi Ikan Teleostei. Yogyakarta, Gajah Mada University Press.

Kultz, D. 2015, Physiological Mechanisms used by Fish to Cope with Salinity Stress, Journal of Experimental Biology 2015 218: 19071914;

Kusrahayu, N. dan Sunaryo, 2007, Keberhasilan Hidup dan Pertumbuhan Benih Ikan Kerapu Dalam Aklimatisasi ke air Tawar Pada Laboratorium (Laporan Penelitian Dosen Muda), Surabaya, Prodi. Pend. Biologi, Fakultas Bahasa dan Sains Universitas Wijaya Kusuma Surabaya.

Maryadi, 2008, Aklimatisasi Benur Udang Windu (Penaeus monodon) Sebagai Upaya Budidaya Di Luar Lingkungan Hidupnya: Sebuah Kasus Di kabupaten Lamongan, Jakarta, Pusat Kebijakan Daya Saing Badan Pengkajian dan Penerapan Teknologi, M.Tek. Ling, Vol. 4, No. 2, 143-152.

Oktarina, R.M., 2009, Pengaruh Frekuensi Perendaman Dalam Air Tawar Terhadap Kinerja Pertumbuhan Ikan Kerapu Tikus (Cromileptes altivels), (Skripsi), Bogor, Fakultas Perikanan dan Ilmu Kelautan, Institut Pertanian Bogor

Appendix A. Subiyakto. S. \& Cahyaningsih. S. 2003. Pembenihan Kerapu Skala RumahTangga, Jakarta, Agromedia Pustaka.

Purcell, M.K. et al, 2008, Adaptation as a potential response to sea-level rise: a genetic basis for salinity tolerance in populations of a coastal marsh fish, Evolu tionary Aplications, 2008 Feb; 1(1): 155-160.

Rachmawati, D. 2012. Domestikasi Keong Macan (Babylonia spirata L.) Melalui Optimalisasi Media dan Pakan (Disertasi). Program Doktor Manajemen Sumberdaya Pantai. Program Pascasarjana. Unive rsitas Diponegoro. Semarang.

Rinen, P.H., 2004, Effects of abrupt cold shock on stress responses and recovery in brown trout exhausted by swimming, Journal of Fish Biology (2004) 64, 1015-1026

Willmer, P. et al, 2005, Environmental Physiology of Animals ${ }^{2 n d}$, Wiley Blackwell, London 